\title{
The effectiveness of the ELT component at the B.Ed. programme in Bangladesh: A critical perspective NASREEN SULTANA
}

\begin{abstract}
The study determines the level of effectiveness of the English course at the B.Ed. programme in Bangladesh in developing professionalism of the prospective English language teachers. Recently, English language teaching has gained momentum because of its local as well as global instrumental use. But, Bangladesh is still facing an acute shortage of skilled English language teachers. Hence, the study investigates the existing structure and the scope of English Language Teaching (ELT) in the teacher training programme of Bangladesh. For this purpose, data has been collected both from trained English language teachers and pre-service trainees to find out the level of success of the ELT course at the B.Ed. programme in Bangladesh. Hence, the study investigates the scope of English language teaching and teacher training with reference to the training institutions in Dhaka, Mymensingh and Comilla.
\end{abstract}

\section{Introduction}

To excel in teaching profession teacher education is imperative. A teacher training programme professionally prepares a teacher for teaching in a classroom. While defining the term teacher education, Hillard (1971) comments, 'teaching is a profession and that teacher education is education for a profession' (p. 33). Thus, teacher education refers to the policies and procedures designed to equip the teachers with the skills, professional attitude and behaviour. Eventually the teachers will perform their tasks effectively in the classroom, school and in the wider community. At the same time it is also an important responsibility of teacher preparation programmes to produce teachers with specialization in various subjects. Specialization is, particularly essential, when it is a question of English language teaching (ELT). Enormous responsibility is devolved on the teachers of English because of the vital place that English occupies in the modern educational 
curricula of the world. English has left its colonial legacy. In countries such as Indonesia and Thailand where there is no trace of British colony, English is used as a second language. In many South-East Asian countries, as Perren (1968) points out, English is used for 'vocational purposes as, it is pre-eminently the language of 'development'; ability to use it may qualify for entry into international community of wealth, power and influence' (p. 3). In all Asian countries, therefore, English is taught as a compulsory subject in schools and Bangladesh is not an exception. However, problem arises when millions of learners are taught English in schools and many learn a little.

If students are not learning, then it is thought that either the teacher or the methods and materials are responsible. However, it may be the fault of the teacher training programmes as well. The training programmes may not be effective to produce efficient language teachers who according to Bailey and Celce-Muria (1979) need professional training and practice. They further observe that only being fluent in English or being native speaker does not qualify someone a prospective teacher for Teaching English as a Second Language (TESL), now thought to be a legitimate profession. Following the similar trend, training the ESL (English as a Second Language) teachers in the teacher education programme in Bangladesh has gained considerable momentum.

Teacher education is one of the important sub-sectors of the education system of Bangladesh. The challenges in the field are enormous, and the formation of a qualified teaching force is an utmost necessity. However, Bangladesh is still faces an acute shortage of skilled English language teachers. Therefore, the teacher education programme in the country needs to be revisited.

In Bangladesh the field of teacher education in ELT is relatively an unexplored area. The inadequacy of professionally trained English teachers is severely affecting the teaching-learning system of English, especially at the secondary level of schooling in the country. The present study explores the B.Ed. English syllabus to get the insight of English teacher education prevailing in Bangladesh. 


\section{Design of the Study}

The study investigates the relation and identifies the need of English language teaching and teacher training with a reference to the existing system of the training institutions of Dhaka, Mymensingh and Comilla. The purpose of the study is not to offer a mere judgment on the success and failure of the B.Ed. course. It scrutinizes the possibility of an improvement on various aspects of the training course.

The research is descriptive, non-experimental and investigative in nature. For this purpose a comprehensible checklist is prepared on the basis of which an evaluative study is made on the English course in the B.Ed. programme. Opinions are collected from the teachers and the trainees. The study examines the data to know how far the B.Ed. English course acquaints the student-teachers with the latest trends of ELT.

\section{Sampling}

The sampling of the study comprises two types of subjects such as, pre-service student-teachers and in-service trained teachers of English at the B.Ed. programme. The subjects are described below:

\section{- Pre-service Student-teachers}

Data are collected from the pre-service trainees who are pursuing the B.Ed. course as prospective English teachers. For the purpose 35 (thirty five) trainees are chosen randomly from three training colleges in Dhaka, Mymensingh and Comilla. They express their opinions, beliefs and classroom experience as regards the English course of the B.Ed. programme.

\section{- In-service Trained Teachers}

35 (thirty five) in-service trained teachers have been selected randomly from six schools in Dhaka, Mymensingh and Comilla. These trained teachers comment on the effectiveness of the B.Ed. English course in the ESL teaching at the secondary level. 
To understand the effectiveness of the English component at the B.Ed programme it is important to make a general survey on various facets of the component.

\section{The English Syllabus of the B.Ed. Course: An Analysis}

The present section analyses the English component of the B.Ed. programme in Bangladesh. The study determines the level of effectiveness of the English course in developing professionalism of the prospective English teachers. For this purpose, a comprehensive checklist is prepared on the various facets of the English syllabus at the B.Ed. course. The present division evaluates the English syllabus on the basis of the checklist.

\section{Checklist to Analyse the English Syllabus of the B.Ed. Programme}

The checklist comprises six areas such as Course Content, Methods in Language Learning and Teaching, Methodology, Instructional Materials and Material Production and Language Testing. Each area has a set of questions on various aspects of the English syllabus for the purpose of analysis.

\section{a) Course Content}

i. Are the course objectives well-suited with the course contents?

ii. Does the English syllabus provide any scope for the teaching of vocabulary and pronunciation?

iii. Does the syllabus maintain a balance between theory and practice?

b) Methods in Language Learning and Teaching

i. What are the methods suggested in the B.Ed. English syllabus?

c) Skills

i. Are all the four skills adequately addressed?

ii. Does the B.Ed. syllabus teach grammar skill?

iii. What types of materials are suggested in teaching the skills?

iv. What are the activities practiced in developing the skills? 


\section{d) Methodology}

i. What types of activities are encouraged in the B.Ed. English syllabus?

ii. Does the B.Ed. English syllabus suggest reflective teaching, selfevaluative teaching and micro-teaching?

iii. Is there any scope for peer-teaching, teaching practice and observing demonstration classes? Are they adequate for the purpose?

iv. Does syllabus propose learner oriented teaching-learning situation?

\section{e) Instructional Aids and Material Production}

i. Does the B.Ed. English syllabus suggest the use of instructional aids?

ii. Does the B.Ed. English component propose the use of films, audio, OHP or any other modern teaching aids?

iii. Is there any scope for training in material production?

\section{f) Language Testing}

i. Does the English syllabus offer any scope for testing the learning outcomes?

ii. Does the B.Ed. English component teach about various factors of testing and test design in language teaching?

\section{Analysis of the B.Ed. English Syllabus}

On the basis of the above checklist, an analysis has been done of the B.Ed. English syllabus of Bangladesh.

\section{a. Course Content}

A good syllabus specifies the goals and objectives in the beginning, so that both the teachers and learners clearly know the aims of the syllabus. It is an essential criterion of an effective syllabus. The B.Ed. English syllabus also lists its objectives and learning outcomes with a detailed description of them. The three objectives are: 
- Develop a personal understanding of ELT based on the knowledge of the pedagogy and the curriculum of English language.

- Develop the knowledge, skills, attitude and practices of ELT to function effectively in the classroom.

- Develop the practices of self-evaluation and reflection for professional improvement as English language teachers.

Now the question is whether these objectives are realized in the course contents of the syllabus. It is desirable that the objectives are related to the course contents so that the course has an overall coherence to the purpose. An overall study of the English syllabus reveals that the English component offers a thorough review on the issues such as the curriculum and the language teaching at the secondary level of Bangladesh and present status and importance of ELT in the global as well as local contexts. This is how the first objective is fulfilled. The second objective is satisfied, as the English syllabus includes the teaching of the four language skills including the grammar skill, introduces various language teaching methods and provides a scope of peer-teaching and practice teaching. These teachings are essential to work as an efficient English language teacher in the secondary classrooms. The third objective also serves the purpose, as the course contents promote the practice of self-evaluation and reflection. Throughout the syllabus, the importance of professional growth and development is emphasized.

To be a skilled English language teacher, it is essential to know how to teach vocabulary and pronunciation. At the same time, these teachings are important in developing the accent and fluency as well. For these purposes the English course of the B.Ed. programme teaches vocabulary, IPA vowel and consonant sounds, stress and intonation and transcription. So it is revealed that vocabulary and pronunciation are taught in the B.Ed. English syllabus.

As far as the issue of balance between theory and practice is concerned, the B.Ed. English syllabus gives equal importance both on theory and practice. The course offers scope for learning about different methods and skills of language teaching and learning. Practice, on the other hand, is always stressed. High level of trainee 
participation is suggested in all levels of training. Practical implication of theories is seen in teaching the four skills and grammar, practicing class management, peerteaching, planning the lessons and teaching practice sessions. The activities are designed in such a way that the trainees are expected to apply their theoretical knowledge in practice. Therefore, it can be said that apparently the B.Ed. English syllabus maintains a balance between theory and practice.

\section{b. Methods in Language Learning and Teaching}

Theories and methods of language teaching play a crucial role in any ESL learning, teaching or training programme. The B.Ed. English component familiarizes the trainees with various methods such as, Grammar Translation Method, Direct Method, Situational Method. Audio-lingual Method, Communicative Approach and Eclectic Method. Following the successful trends of English language teaching, the syllabus stresses on Communicative Language Teaching (CLT) to teach the language. The trainees are encouraged to use CLT in teaching the language as teachers.

\section{c. Skills}

The basic language skills such as, listening, speaking, reading and writing are crucial in teaching-learning of any language. The B.Ed. English course suggests the teaching of the four language skills. Additionally, the syllabus offers the basic theoretical knowledge also in teaching the four language skills. Various types of activities such as group/pair discussion, planning, video observation, role-play, mind-mapping, case studies etc. are suggested in teaching the four language skills. However, no guideline is given to practice these activities in teaching the four skills. At the same time, the English syllabus does not suggest what kind of materials should be used in teaching the skills. However, the Curriculum Framework, 2006 of Bangladesh encourages the subject teachers to use different types of electronic resources as well as the locally available resources in teaching the language. Therefore, it seems that the use of materials depends on the skill of the trainers. The trainers need to be innovative and competent enough to use the materials what they think suits the need of the class. 
Grammar skill is also included in the syllabus for the purpose of accuracy. Structure and lexis of English, informal and formal grammar, and grammar analysis is incorporated in the English course. However, the syllabus does not include the grammar activities to teach the skill.

After the study of the syllabus, it can be said that though the English component of the B.Ed. syllabus offers ample scope for teaching the four language skills, clear guideline is not given on how to teach the skills. The activities are listed randomly without proper instruction of how to use them in teaching four different language skills.

\section{d. Implementation of Methodology}

The B.Ed. English syllabus involves the student-teachers in various activities such as, group/pair discussion, debating, role play, case studies, jigsaw tasks, problem solving, mind mapping and brain storming etc. The concepts of encouragement and support, involvement and skills of teaching are developed by using these activities.

The principles of the B.Ed. syllabus are based on the concepts of the reflective and self-evaluative teaching and the microteaching. The student-teachers are taught to maintain reflective journal so that they learn to evaluate their own learning and teaching. In support of the concepts, learning activities includes action research techniques, case studies, simulations and microteaching modeling.

The study reveals that the B.Ed. syllabus offer adequate scope of peer-teaching and practice teaching. Peer-teaching prepares the trainee-teachers for practice teaching. Moreover, they observe videos and classes to learn different teaching skills. During the practice teaching 1, the student-teachers observe the real classes and later on they also conduct some real classes. The teacher-educators give them feedback and based on the feedback they take preparation for practice teaching 2 . In addition, the B.Ed. English component teaches lesson planning. The studentteachers go through the sessions of simulations and they improve their lessons based on the feedback of the fellow trainees and teacher educators. Therefore it is 
noted that the English component provides ample scope for peer-teaching and practice teaching.

It is further noted that the syllabus suggests a learner-oriented teaching-learning situation. The activities are designed in such a way that it promotes a traineecentered environment in the classroom. The teacher educators are supposed to act as facilitators. However, the implementation of the methodology largely depends of the teacher educators.

\section{e. Instructional Aids and Material Production}

Teaching aids play a crucial role in making the teaching-learning situation a success. The use of modern teaching aids can create interesting learning environment. Nonetheless, the B.Ed. English syllabus mentions the use of blackboard in the training classes. Apparently, it does not promote the use of modern instructional materials such as, $\mathrm{OHP}$ or PowerPoint. However, it encourages observing demonstration videos to train the student-teachers and identifying of supplementary resources and teaching aids.

The B.Ed. English syllabus does not offer any scope for teaching material production in the classroom. The syllabus suggests the trainees to be proactive and inventive in locating the resources available in the limited contexts where they will teach. But the trainee teachers do not get opportunity to learn about various concepts of producing realistic materials.

\section{f. Language Testing}

To assess the learning of the student-teachers' various tests such as, interviews, presentations, assignments, term tests, critique of journal papers, internal examination and final examinations are conducted. The student-teachers undergo simulation and peer-teaching session which also may confirm the learning of the trainees. Further, the B.Ed. English syllabus teaches the concept of testing in language teaching. The trainees are taught about test items, Bloom's taxonomy in language teaching, testing the four skills, formative and summative assessment. However, types of test, modes of test, how and what to test in testing four language 
skills and details of test design are not included in the syllabus. The analysis reveals that the English syllabus of the B.Ed. programme advocates a brief concept of testing. It does not offer a comprehensive study of language testing.

The next section reports data analysis and the findings of the study.

\section{Data Analysis}

The questionnaires (Appendix 3 and 4) for the pre-service student-teachers and in-service trained teachers contain 17 (seventeen) questions each. They are similar in structure and content. Some questions are close-ended and some are open-ended. Most of them are followed by a set of multiple answers and the respondents are supposed to tick the one, they consider right. In addition, there is a 3-point scale question where they are to circle the number against the idea they agree with.

The Questionnaires (Appendix 3) were distributed to the randomly chosen preservice trainees in three training colleges of Dhaka, Mymensingh and Comilla. First, the researcher explained the format of the questionnaire and gave them sufficient time to answer the questions. Many of them filled the questionnaires on the day and few of them took the questionnaires home to complete and returned them on the following day. The student-teachers were given complete freedom to express their opinions.

The Questionnaires (Appendix 4) for the in-service trained teachers were circulated among the teachers of the six schools in Dhaka, Mymensingh and Comilla. The teachers were randomly selected. The researcher explained the design of the questionnaire and requested them to offer their responses. They were given adequate time and liberty to respond. Many teachers, because of busy schedule, preferred to take the questionnaires home to complete and to return them on the following day.

\section{Findings and Suggestions}

The responses of the pre-service trainees and in-service trained teachers are the primary source of information for the present research. Their opinions and 
experiences regarding the B.Ed. English programme draw up appropriate guidelines on how to determine the effectiveness of the programme. After analyzing the data some important outcomes are found out, such as:

1. The undertaken study shows that both the pre-service trainees and the inservice trained teachers hold a positive attitude towards the overall B.Ed. programme. The sample trainees particularly opt for this course to be efficient English teachers and to improve their teaching skills. On the other hand, there are many who pursue the B.Ed. programme for a better job prospect. It, therefore, seems that the B.Ed. programme does have a highly lucrative and professional value in the field of teaching.

2. The English component of the B.Ed. programme teaches different methods and approaches, so that the trainees can apply them as teachers. Though methods such as Audio-Lingual and Grammar Translation are taught, the trainees are encouraged to apply Communicative Language Teaching (CLT) and Situational Approach in keeping with the present trend of English language teaching.

3. The pre-service respondents have expressed their satisfaction on the teaching of four language skills i.e., listening, speaking, reading, writing, and on the teaching of grammar skill as well. The analysis reveals that the opinions of the pre-service trainees, to some extent, differ from some responses of their inservice counterparts. Critically reviewing the teaching of the skills, few veteran teachers consider it rather ineffective in a real classroom. It may be a reflection of some individual incapacity rather than some intrinsic teaching flaws.

4. The respondents want ELT as the core component in the B.Ed. programme. Such a demand indirectly voices the need of skilled learning of English to facilitate teaching of other subjects the materials of which are largely archived in English. The study reveals that both English and Bangla are used as a medium of instruction in the training classes. English to Bangla code-switching is commonly used for the convenience of the student-teachers coming from the vernacular medium. A gap between the objective of the B.Ed. English syllabus and the teaching of the English component is rather evident in this context. The 
objective of the B.Ed. English programme advocates in favour of the CLT approach but the educators sharply deviates from it in practice and allows the use of the mother tongue of the trainees i.e. Bangla with English, the target language. Such practice is smoothly copied and mapped by the trainees on their teaching domains. Eventually, this will pose a threat to the success of CLT.

5. The English component of the B.Ed. syllabus seems to be helpful in teaching English language at the secondary level. Many pre-service student-teachers find it modern and it maintains a proper balance between theory and practice. The study reveals that by and large the English classes are informative. However, it is noted that the classes are lecturer oriented. Therefore, few inservice teachers feel that the English classes are mechanical. Some of them feel that though the present B.Ed syllabus is relevant for teaching at the secondary level it leaves ample scope for revisions.

6. As far as the instructional aids are concerned, it is found that modern teaching aids such as over-head projectors, films and PowerPoint presentations are minimally used. Instead, traditional aids such as handouts and posters are used in the training classes. Such a preference indicates the absence of required infra-structure for using modern instructional aids and the cost-effectiveness of the traditional aids.

7. The B.Ed. English programme offers ample scope for peer-teaching and discussion, which prepares the trainees for the practice teaching sessions. Generally, the allotted time to perform the task of peer-teaching lasts for 10 to 20 minutes. Commenting on the scope for practice teaching, pre-service student-teachers express their dissatisfaction whereas their counterparts are satisfied in this regard. It is noted that though there is a mixed response as regards the scope for practice teaching, the respondents from both the groups are pleased with the time allotted to practice teaching.

8. Finally, it is revealed that the B.Ed. English syllabus teaches modern concepts such as micro-teaching and macro-teaching. Encouragingly, the B.Ed. students 
are trained to reflect on and self-evaluate their teaching. It is also found that the present time duration of the B.Ed. programme, that is, one year is fairly adequate in developing the teaching skills of the participants. Regrettably, the training institutes are reluctant in arranging seminars or workshops on ELT to expand the professional knowledge of the trainees.

On the basis of the analyzed data and the findings, the undertaken study recommends the following suggestions. It is assumed that the implementation of these proposals will bring out positive changes in the B.Ed. programme and in its English component. The suggestions are given below:

1. The teacher training institutions need to consider increasing the infrastructural facilities so that the modern teaching aids can be used frequently for the benefit of the trainees. This apart, the institutions should stress on the use of films where desired teaching strategies and behaviours are demonstrated to create a definite learning impact, ensuring the effectiveness of teaching.

2. ELT should be given the status of a compulsory subject in the B.Ed. course. One cannot deny the role of English as a library language. The reference books and resources are largely available in English. Eventually, the knowledge of English will help the teachers in teaching other subjects as well.

3. It is strongly recommended that the duration of the B.Ed. course should be increased from 12 months to18 months. The trainee teachers will get enough time to learn the theories and to apply them in teaching practice.

4. ELT workshops and seminars should be held regularly at the training institutions. As teachers of English language, it is imperative to be aware of the on-going developments and changes in the field of ELT. The workshops will offer the trainees a glimpse of the current issues in ELT.

5. Instead of practice teaching sessions, the B.Ed. programme should introduce internship in teaching. The trainee teacher will work as intern 
teachers in schools for a specific duration of time. The internship will offer the student-teachers to work as real teachers in the classrooms. While working as interns, they will learn about the curriculum, syllabus, students and the system of teaching. In this regard, the respective training institutions should offer placement for the student-teachers as interns in schools.

6. It is recommended that the B.Ed. English course should train the course participants in material production. To implement the ESL syllabus, the teachers, in addition to, the prescribed textbook are required to produce realistic supplementary study materials. To produce effective study materials for the classroom, the teachers need both theoretical and practical exposure to material production. Therefore, the English syllabus at the B.Ed. programme needs to incorporate material production to train the student-teachers adequately.

7. The B.Ed. English syllabus needs to offer a comprehensive training in language testing. Designing tests for the language learners plays a crucial role in determining the learning outcome. The B.Ed. English course needs to incorporate the theoretical and the practical aspects of language testing, so that the trainee-teachers can work efficiently as test designers while teaching the ESL learners.

8. The budget for improving the teacher education sector should be increased. The inadequate infra-structure of the training colleges can be improved provided the government offers adequate financial support. If the infra-structure is improved, other problems related to teaching aids and study materials can be solved.

9. Bangladesh follows a uniform B.Ed. curriculum, ESL syllabus and textbook (secondary level). Therefore, any modification in the respective areas can be implemented quite comfortably. 


\section{Works Cited}

National University. (2006). Bachelor of education curriculum. Gazipur.

Bailey, K. M., \& Celce-Muria, M. (1979). Classroom skills for ESL teachers. In M. CelceMurcia and L. McIntosh (Ed.), Teaching English as a second or foreign language (p. 315331). Massachusetts: Newbury House Publishers, Inc.

Hilliard, F. H. (1971). Theory and practice in teacher education. In F. H. Hilliard (Ed.), Teaching the teachers: Trends in teacher education (p. 33-43). London: George Allen and Unwin Ltd. Foundation.

Perren, G. E. (1968). Introduction. In G. E. Perren (Ed.), Teachers of English as a second language (p. 1-13). Cambridge: Cambridge University Press.

Teacher Education Institutes in Bangladesh. (n.d.). Retrieved from http://www.teachereducation.gov.bd/

\section{References}

Aggarwal, J.C. (2004). Teacher and education in a developing society. $4^{\text {th }}$ ed. Delhi: Vikas Publishing House Pvt. Ltd.

Aggarwal, J. C. (2005). Teacher education: Theory and practice. Delhi: Doaba House.

Richards, J. C., \& Nunan, D. (Eds.). (1990). Second language teacher education (p. xi).

Cambridge: Cambridge University Press.

Shaw, P. (1979). Handling a language component in a teacher training course. In S. Holden

(Ed.), Teacher training (p. 12-15). London: Modern English Publications.

Smith, D. A. (1968). In service training for teachers of English in developing countries. In

Perren, G. E. (Ed.), Teachers of English as a foreign language: Their training and

preparation (p. 180-207). London: Cambridge University Press.

Taylor, D. S. (1985). “The Place of methodology in training of language teachers and the integration of theory and practice." System, 13 (1), 37-41.

Wallace, M. J. (1991). Training foreign languages teachers: A reflective approach. Cambridge: Cambridge University Press. 


\section{Appendix 1}

Names of the secondary schools visited for data collection:

1. Biddamayi Sorkari Balika Uccha Biddalaya, Mymensingh

2. Patgudam Balika Uccha Biddalaya, Mymensingh

3. Ideal School and College, Motijheel, Dhaka

4. Siddeshwary Boy's Higher Secondary School

5. Nabab Faizunnesa Shorkari Balika Uccha Biddalaya, Comilla

6. Comilla Zilla School, Comilla

\section{Appendix 2}

Names of the B.Ed. colleges visited for data collection:

1. Teacher's Training College, Dhaka

2. Govt. Teacher's Training College, Comilla

3. Teacher's Training College (Women), Mymensingh

\section{Appendix 3}

\section{Questionnaire to Pre-service Student-Teachers}

The following questionnaire seeks information on the nature of teacher training, on your experience as a trainee, and your beliefs and opinions on the teaching-learning situation of English at the B.Ed. Program.

There are some questions followed by a set of answers. You need to choose the relevant one(s) and put a $(\sqrt{ })$ mark. There are also some yes/no questions. You need to tick either Yes or No according to your opinion. These apart, you require to answer some openended questions briefly. There is a question in 3- point scale where you need to circle the appropriate number against the idea you agree with.

The information given by you will be strictly confidential and meant only for research purposes. Your co-operation is, therefore, earnestly sought. Thank you.

\section{Name:}

Age : 
Gender: Male/Female

Educational Qualification:

Professional Qualification (If any):

Experience (If any):

Name of the College:

Affiliated to:

1. Why do you pursue the B.Ed. course?
a. For a better job prospect
b. To improve English teaching skill
c. Did not have any other option
d. Any other (specify)

2. Given below are some comments on the English component in your B.Ed. syllabus. Please indicate how far you agree with each comment. Number them according to the following scale.

$$
\text { 1= agree } \quad 2=\text { disagree } \quad 3=\text { partly agree }
$$

a. The English course of the B.Ed. syllabus will be helpful in class room teaching 123

b. The English syllabus is up to date and acquaint the teachers with modern techniques of language teaching

123

c. The English syllabus teaches how to use different teaching methods in class 123

d. The English syllabus does not put emphasis on listening and speaking $1 \quad 2 \quad 3$

e. The present English syllabus does not maintain a balance between theory of language teaching and practice

$1 \quad 2 \quad 3$

3. Should ELT be a compulsory component in the B.Ed. programme?
a. Yes
b. No 
4. Is the present B.Ed. course relevant for the teachers teaching English at the Secondary level?
a. Yes
b. No

5. Your English class is, (tick $(\sqrt{ })$ the relevant answer)
a. Mechanical and monotonous
b. Informative
c. Trainers-centered
d. Trainee-centered
e. Good for enhancing teaching skills in general
f. Helpful in improving and developing English language teaching skills

6. What is the medium of instruction in your English class?
a. Only English
b. Only Bangla
c. Both English and Bangla

7. In relation to the B.Ed. English course, give you opinion on the effectiveness of teaching in the following areas. Circle the appropriate number according to the following scale

$\begin{array}{cccc}\mathbf{1 =} \text { Good } & \mathbf{2 =} \text { Satisfactory } & & \mathbf{3}=\text { unsatisfactory } \\ \text { Listening } & 1 & 2 & 3 \\ \text { Speaking } & 1 & 2 & 3 \\ \text { Writing } & 1 & 2 & 3 \\ \text { Reading } & 1 & 2 & 3 \\ \text { Grammar } & 1 & 2 & 3\end{array}$

8. Please indicate the approximate time distribution by your teachers for the following activities in $\%$
a. Lecture (monologue) $\ldots \ldots \ldots \ldots \ldots . . . . \%$
b. Instruction .........................\%
c. Teacher-student discussion..........\% 
d. Peer-discussion....................\%

9. Which of the following teaching aids are used in your classroom?
a. Over-head Projector (OHP)
b. PowerPoint Presentation (PPT)
c. Radio
d. Tape recorder
e. Handouts
f. Films, audios/videos
g. Others (Please specify)

10. What are the approaches and methods your teachers want you to use for the learners? Please specify the relevant answer(s).
a. Grammar-translation method
b. Audio-lingual method
c. Bilingual method
d. Communicative approach
e. Situational approach
f. Any other (Please specify)

11. Do you get training to reflect on and self-evaluate your teaching?
a. Yes
b. No

12. (i) Does the B.Ed. English syllabus offer ample scope for practice teaching?
a. Yes
b. No

(ii) If 'YES', do you find the time allotted to practice teaching adequate?
a. Yes
b. No

13. (i) Does the B.Ed. English syllabus provide any scope for peer-teaching?
a. Yes
b. No

(ii) If your response is 'YES', please mention the time allotted to it. 
14. Do you learn and practice the concept of micro-teaching and macro-teaching?
a. Yes
b. No

15. Do you feel that the present one-year duration of the B.Ed. program is justified in developing the teaching competencies in the student-teachers?
a. Yes
b. No

16. Are films/audios/videos containing demonstrative desired teaching strategies and behaviours used in your class?
a. Yes
b. No

17. Do your B.Ed. college organize workshops or seminars?
a. Once in a year
b. Twice in a year
c. Never
d. Any other (Please specify)

\section{Appendix 4}

\section{Questionnaire to In-service Trained Teachers}

The following questionnaire seeks information on the nature of teacher training, on your experience as a trained teacher, and your beliefs and opinions on the teaching-learning situation of English at the B. Ed. Program.

There are some questions followed by a set of answers. You need to choose the relevant one(s) and put a $(\sqrt{ })$ mark. There are also some yes/no questions. You need to tick either Yes or No according to your opinion. These apart, you require to answer some openended questions briefly. There is a question in 3- point scale where you need to circle the appropriate number against the idea you agree with.

The information given by you will be strictly confidential and meant only for research purposes. Your co-operation is, therefore, earnestly sought. Thank you.

\section{Name:}

Age :

Gender: Male/Female 
Educational Qualification:

Professional Qualification (If any):

Medium of Instruction: Bangla/English/Both

Name of the College:

Affiliated to:

Teaching Experience:

1. Why did you pursue the B.Ed. course?
a. For a better job prospect
b. To improve English teaching skill
c. Did not have any other option
d. Any other (specify)

2. Given below are some comments on the English component in your B.Ed. syllabus. Please indicate how far you agree with each comment. Number them according to the following scale.

$$
\text { 1= agree } \quad 2=\text { disagree } \quad 3=\text { partly agree }
$$

a. The English course of the B.Ed. syllabus will be helpful in class room teaching 123

b. The English syllabus is up to date and acquaint the teachers with modern techniques of language teaching

123

c. The English syllabus teaches how to use different teaching methods in class

123

d. The English syllabus does not put emphasis on listening and speaking 123

e. The present English syllabus does not maintain a balance between theory of language teaching and practice $1 \quad 2 \quad 3$

3. Should ELT be a compulsory component in the B.Ed. programme?
a. Yes
b. No 
4. Is the present B.Ed. English course relevant for the teachers teaching English at the Secondary level?
a. Yes
b. No

5. Your English class was, (tick $(\sqrt{ })$ the relevant answer)
a. Mechanical and monotonous
b. Informative
c. Trainer-centered
d. Trainee-centered
e. Good for enhancing teaching skills in general
f. Helpful in improving and developing English language teaching skills

6. What was the medium of instruction in your English class?
a. Only English
b. Only Bangla
c. Both English and Bangla

7. In relation to the B.Ed. English course, give you opinion on the effectiveness of teaching in the following areas. Circle the appropriate number according to the following scale.

$\begin{array}{llll}\mathbf{1 =} \text { Good } & \mathbf{2}=\text { Satisfactory } & \mathbf{3}=\text { unsatisfactory } \\ \text { Listening } & 1 & 2 & 3 \\ \text { Speaking } & 1 & 2 & 3 \\ \text { Writing } & 1 & 2 & 3 \\ \text { Reading } & 1 & 2 & 3 \\ \text { Grammar } & 1 & 2 & 3\end{array}$

8. Please indicate the approximate time distribution by your teachers for the following activities in \% 

a. Lecture (monologue)..............\%
b. Instruction .........................\%
c. Teacher-student discussion..........\%
d. Peer-discussion....................\%

9. Which of the following teaching aids were used in your classroom?
a. Over-head Projector $(\mathrm{OHP})$
b. PowerPoint Presentation (PPT)
c. Radio
d. Tape recorder
e. Handouts
f. Films
g. Others (Please specify)

10. What were the approaches and methods your teachers wanted you to use for the learners? Please specify the relevant answer(s).
a. Grammar-translation method (GTM)
b. Audio-lingual method (ALM)
c. Bilingual method
d. Communicative approach
e. Situational approach
f. Any other (Please specify)

11. Did you get training to reflect on and self-evaluate your teaching?
a. Yes
b. No

12. (i) Did the B.Ed. English syllabus offer ample scope of practice teaching?
a. Yes
b. No

(ii) If 'YES', do you find the time allotted for practice teaching adequate?
a. Yes
b. No

13. (i) Did the B.Ed. English syllabus provide any scope for peer-teaching? 

a. Yes
b. No

(ii) If your response is 'YES', please mention the time allotted to it.

14. Did you learn and practice the concept of micro-teaching and macro-teaching?
a. Yes
b. No

15. Do you feel that the present one-year duration of the B.Ed. programme is justified in developing the teaching competencies in the student-teachers?
a. Yes
b. No

16. Were films/audios/videos containing demonstrative desired teaching strategies and behaviours used in your class?
a. Yes
b. No

17. Did your B.Ed. college organize workshops or seminars?
a. Once in a year
b. Twice in a year
c. Never
d. Any other (Please specify) 